\title{
Intermittent Exotropia
}

\section{Dr Partha Haradhan Chowdhury ${ }^{1 *}$ and Brinda Haren Shah ${ }^{2}$}

${ }^{1}$ Ph.D. in Optometry (Gujarat State Government University) and Professor and

Principal, Shree Satchandi Jankalyan Samiti Eye Institute - Pauri, Uttarakhand, India

${ }^{2}$ M. OPTOM, Practitioner, Ahmedabad, Gujarat, India

*Corresponding Author: Dr Partha Haradhan Chowdhury, Ph.D. in Optometry (Gujarat State Government University) and Professor and Principal, Shree Satchandi Jankalyan Samiti Eye Institute - Pauri, Uttarakhand, India.
Received: March 23, 2021

Published: April 15, 2021

(C) All rights are reserved by Dr Partha

Haradhan Chowdhury and Brinda Haren

Shah.

\section{Abstract}

This paper describes about introduction to intermittent exotropia, its classification and treatment.

Keywords: Intermittent Exotropia; Classification; Treatment

\section{Introduction}

It is a very common type of exotropia. It mainly occurs in the childhood or Infant. It is a large phoria and this phoria is usually maintained by fusional convergence. It occurs intermittently because always it is not found. This tropia always persist with clinical features:

- When patient is too tired, the eye is deviated

- During alcoholism

- During cold etc.

In case of intermittent exotropia, fusion breaks spontaneously unlike other exophoria. Intermittent exotropia is in two phases, when fusion is maintained then normal retinal correspondence persists. When fusion is not maintained then it is converted into abnormal retinal correspondence. In NRC phase, good stereoacuity is present.

When patient comes to clinic, then proper history should be taken before proceeding to take visual acuity. If intermittent exo- tropia is present and unknowingly visual acuity is measured, then normal retinal correspondence phase will be converted into abnormal retinal correspondence.

In case of intermittent exotropia, there will be difference in deviation between distance and near.

Classification:

- Basic intermittent exotropia

- Pseudo divergence excess

- True divergence excess.

\section{Basic intermittent exotropia}

Here, deviation between distance and near is not considerable, it is within $10 \mathrm{PD}$.

\section{Pseudo divergence excess}

At first, distance and near deviation is difference is more than 10 PD. After prolonged occlusion (30 minutes to 60 minutes patch 
test), this deviation difference is reduced and comes within 10 PD. It means, near exophoria becomes more exophoric.

E.g.

Distance - 30 PD Exo

Near - 10 PD Exo

After Patch Test

Distance - 30 PD Exo

Near - 25 PD Exo.

True divergence excess

Here, after patch test also, difference between distance and near deviation will not come within 10 PD.

E.g.:

Distance - 40 PD Exo

Near - 10 PD Exo

After Patch Test

Distance - 40 PD Exo

Near - 25 PD Exo.

\section{Treatment}

Usually up to -2 to -3 D overcorrection of minus should be prescribed.

Mono occlusion is prescribed to the patient (up to 3 to 4 hours and take rest and continue again).

If Intermittent exotropia is persisting is $>50 \%$ in waking hours, then bilateral LR recession surgery is advised and need to create 8 to 10 PD esotropia [1-3].

\section{Bibliography}

1. William J Benjamin. "Borish's Clinical Refraction". $2^{\text {nd }}$ Edition (2006).

2. Theodore Grosvenor and Theodore P Grosvenor. "Primary Care Optometry". $5^{\text {th }}$ Edition (2007).

3. Sir Stewart Duke-Elder and David Abrams. "Duke Elder's Practice of refraction" (1978).

\section{Assets from publication with us}

- Prompt Acknowledgement after receiving the article

- Thorough Double blinded peer review

- Rapid Publication

- Issue of Publication Certificate

- High visibility of your Published work

Website: www.actascientific.com/

Submit Article: www.actascientific.com/submission.php

Email us: editor@actascientific.com

Contact us: +919182824667 